\title{
Mad Rita
}

\author{
Darlene Searcy
}

\section{Rita la folle}

Pauvre Rita qui écrit ses mémoires avec sa plume trempée de douleur à coup de dictionnaire et devient folle. Quiva acheter le livre d'une ancienne douleur?

Poor Rita.

But you've got to control your life.

Do you suppose she made

the highest bid

and so sold she

spent time, floating perhaps,

on a distant dream?

Gulping brandy and cooling her wings.

Writing her memoirs, pen filled with pain.

A thesaurus nearby.

Do you suppose poor mad Rita

speculates now

on who carries the box

remembering brings?

Who lets it slide off from

shoulder to earth

then picks up the dirt

to try to cover the box?

Who feeds its hunger,

who feels the pain?

Who'll buy the book

of an old ache again? 